\title{
ASSESSING TORONTO'S MINIMUM PARKING REQUIREMENTS FOR CONDOMINIUMS
}

\author{
By Graham Haines \\ BASc, University of Toronto 2007 \\ A Major Research Paper \\ presented to Ryerson University \\ in partial fulfillment of the requirements for the degree of \\ Master of Planning \\ In \\ Urban Development
}

Toronto, Ontario, Canada, 2014

(C) Graham Haines 2014 


\section{Author's Declaration}

I hereby declare that I am the sole author of this major research paper. This is a true copy of the major research paper, including any required final revisions, as accepted by my examiners.

I authorize Ryerson University to lend this major research paper to other institutions or individuals for the purpose of scholarly research

I further authorize Ryerson University to reproduce this major research paper by photocopying or by other means, in total or in part, at the request of other institutions or individuals for the purpose of scholarly research.

I understand that my major research paper may be made electronically available to the public. 


\title{
ASSESSING TORONTO'S MINIMUMS PARKING REQUIREMENTS FOR CONDOMINIUMS
}

\author{
(C) Graham Haines, 2014 \\ Master of Planning \\ In \\ Urban Development \\ Ryerson University
}

\begin{abstract}
This research explores whether Toronto's minimum parking requirements for condominiums are actively and effectively implementing policy goals expressed by the Province and the City and if Toronto's parking requirements are acting as a barrier to development. Through a review of existing literature, an analysis of the process used to set Toronto's current parking requirements, and field interviews with condominium developers it is determined that the current requirements actively work against policies aimed at reducing car dependence and have harmful impacts to development. On the basis of these findings recommendations are made to planners and developers in order to improve parking management and policy.
\end{abstract}

Key Words: City of Toronto; Mobility; Parking; Urban development; Zoning by-law; 


\section{DEDICATION}

I would like to offer my most sincere appreciation to my project supervisor, Dr. Pamela Robinson.

Dr. Robinson offered more support and encouragement than I could have ever asked for. I would also like to thank my second reader Dr. David Amborski for his input and support.

Thank you to all of my friends - I doubt this MRP would have been possible without regular escapes. Thank you as well to my family for their support through a time filled with change for us all. Finally, thank you to Megan Desjardins for her support through a hectic few months. 


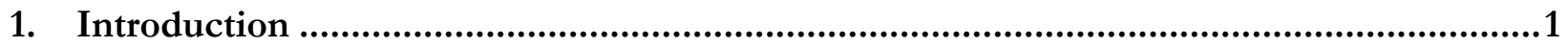

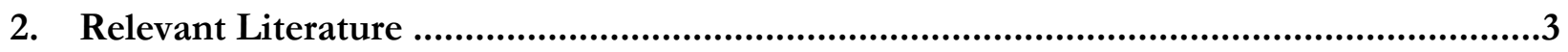

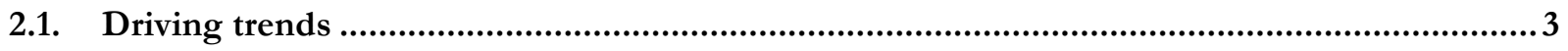

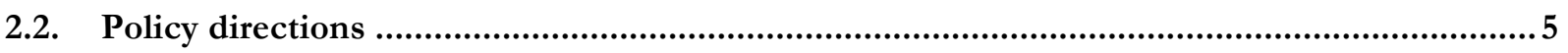

2.3. The justification for minimum parking requirements .......................................................6

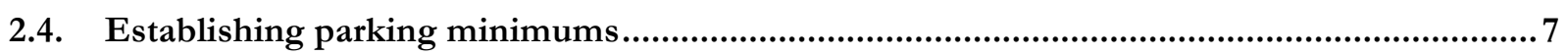

Critique of the traditional parking requirement methodology ...............................................................

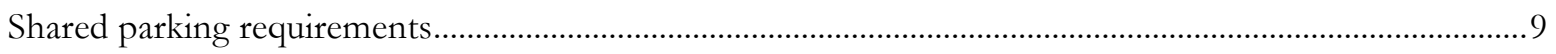

Reducing the need for parking at residential buildings ...........................................................................11

A new method to set minimum parking requirements ................................................................................11

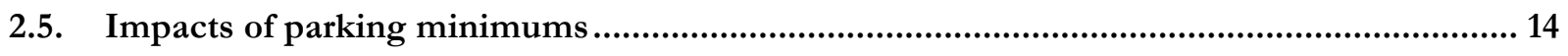

Impacts on mode choice ................................................................................................................ 15

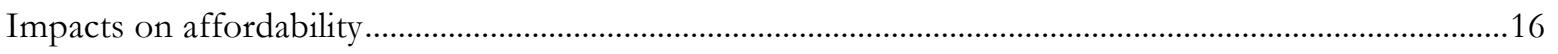

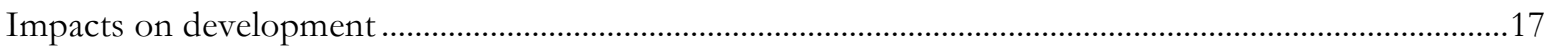

2.6. Public perception of parking requirements..................................................................... 18

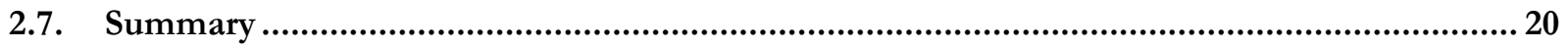

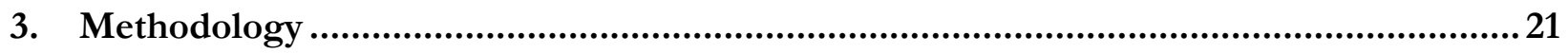

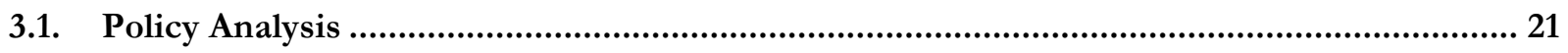

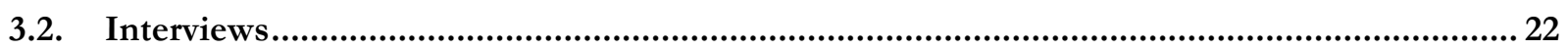

4. Parking Requirements in Toronto.........................................................................24

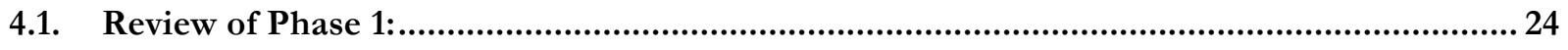

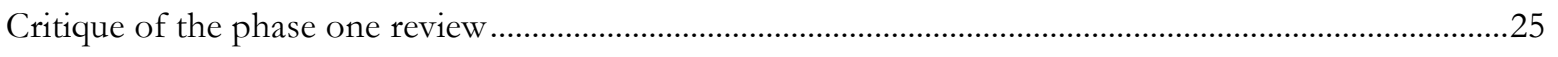

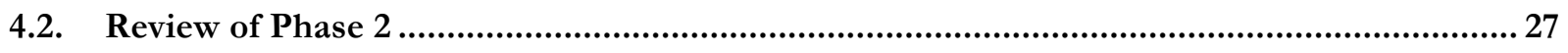

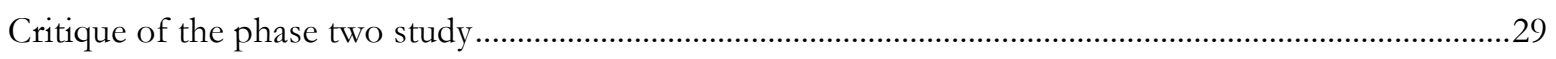


4.3. Assessment of the Current Parking Requirements ............................................................. 31

Critique of Toronto's Current Parking Requirements ....................................................................................33

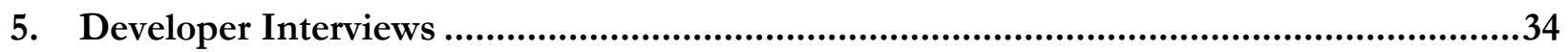

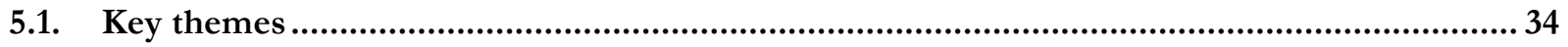

Theme \#1: Location and target market have the most significant impact on parking................................34

Theme \#2: Parking typically generates losses, not profits .............................................................................35

Theme \#3: Parking supply has had an impact on the current price of residential units .............................35

Theme \#4: Parking requirements reduce development feasibility...................................................................36

Theme \#5: Eliminating parking minimums would not significantly impact the amount of parking

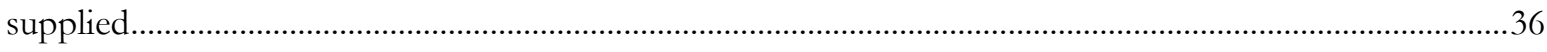

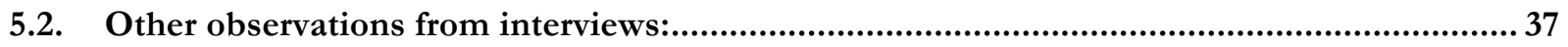

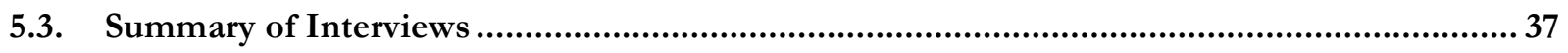

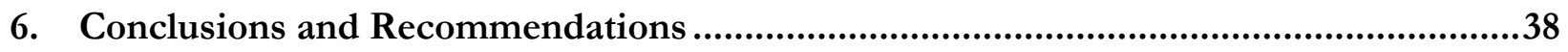

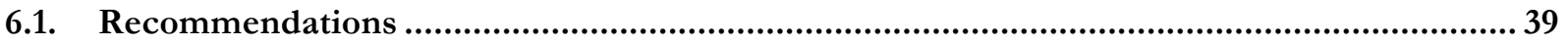

Recommendation 1: Municipal planners should reform Toronto's parking requirements.........................39

Recommendation 2: Urban planners require better education about parking ............................................41

Recommendation 3: Developers should track and publish parking sales ....................................................43

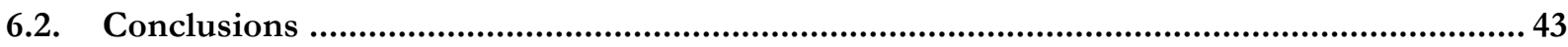




\section{List of Tables}

Table 1: Residential Parking Survey Responses .................................................................................... 27

Table 2: Condominium Auto Ownership (Vehicles/Unit). Adapted from Cansult, 2007.................. 28

Table 3: Cansult proposed residential parking requirements (Cansult, 2007) ..................................... 29

Table 4: City of Toronto Parking Minimums and Maximums (City of Toronto, 2013)....................... 32

\section{List of Figures}

Figure 1: VKT/Vehicle and VKT/Capita in Canada......................................................................... 5

Figure 2: VKT/Vehicle and VKT/Capita in Ontario.......................................................................... 5

Figure 3: Comparison of traditional and shared parking requirement calculations.............................. 10

\section{List of Appendices}

Appendix A - Interview Guide 44 


\section{Introduction}

Minimum parking requirements have a significant impact not just on automobile use, but they lead to significant infrastructure investments that will increasingly sit empty and/or contain unused vehicles as planners implement smart growth policies and as mobility trends continue to change. Strong consideration for new thinking about parking is warranted on the basis of these changing trends. Unfortunately reforming minimum parking requirements is not an easy task. Minimum parking requirements at new condominiums have been a growing source of contention in Toronto developers frequently seek reductions to parking requirements for new developments in existing neighbourhoods, arguing that the current minimum requirements force an oversupply of parking; on the other-side of the argument councillors, local residents, and planners often oppose these reductions on the basis of impacts to the existing supply of parking, particularly on-street parking. There does seem to be some credence to the perspective advanced by developers - polls suggest that North Americans are driving less, particularly the millennial generation. Ignoring these trends is likely to lead to an oversupply of parking, wasting space and development resources, as well as impacting the affordability of new development projects.

In order to promote an informed discussion about future minimum parking requirements at condominiums this project assesses the impacts of Toronto's current parking requirements for condominiums. There is a focus on understanding how the existing requirements impact development, and our ability to meet goals expressed at the municipal and provincial levels relating to mode choice. To carry this assessment out the current parking requirements are studied through three lenses:

First, from a broad perspective the impacts of parking requirements are studied through a review of academic research. This review is meant to provide an understanding of how parking requirements 
can impact mode choice and development; Second, the process used to set Toronto's current parking minimums is analyzed to understand how and why parking minimums were set at their current level; Third, field interviews were carried out with condominium developers in Toronto to assess the impacts of Toronto's parking requirements on the development of condominiums in Toronto.

The results of these reviews are used to inform a discussion of the performance of Toronto's current minimum parking requirements. The following questions drive this analysis:

1. Are Toronto's minimum parking requirements actively and effectively implementing policy goals expressed by the Province and the City? In particular are Toronto's parking requirements reflective of goals to reduce dependence on automobile trips?

2. Are Toronto's parking requirements acting as a barrier to development?

Finally, this report reflects on opportunities to reform and improve Toronto's parking requirements and offers recommendations to municipal planners, urban planners in general, and to developers. 


\section{Relevant Literature}

Prior to the $21^{\text {st }}$ century parking was typically viewed as a necessary facility, required to support the efficiency of the overall transportation system. As a result, for most of the $20^{\text {th }}$ century parking policy was not studied in depth by academics (Ben-Joseph, 2012; ITDP, 2010; Speck, 2012) - traffic engineers carried out some work aimed at determining appropriate levels of parking requirements, but the overall impacts of parking were largely ignored (Ben-Joseph, 2012). However, in the $21^{\text {st }}$ century, along with a more critical look at the impacts of driving in general, parking has been studied more critically. Led by Donald Shoup's The High Cost of Free Parking (2011), academic literature and studies have found that parking minimums distort the economics of our transportation system and subsidize the decision to drive. As urbanization continues, and the need to drive decreases, requiring minimum levels of parking runs counter to societal trends and the preferences of many individuals particularly individuals under the age of 34 who are less interested in car ownership than older generations (Baxandall, Davis, and Dutzik, 2012).

\subsection{Driving trends}

Current literature suggests that automobile dependency is decreasing in North America, particularly among younger generations (Baxandall, Davis and Dutzik, 2012). In the U.S.A. annual VKT peaked in 2004 and has been on the decline ever since, suggesting a shift away from automobile based travel (Ibid). A study conducted at the University of Michigan found similar results, suggesting that the number of households without vehicles was increasing (Sivak, 2014), and that individuals are driving less than they used to (Sivak, 2013).

These trends are even more pronounced for younger generations, particularly millennials (or Generation Y). A survey of American drivers found that millenials are less likely to have drivers' licences and the primary reasons are the perceived costs of driving and that they are too busy 
(Schoette, and Sivak, 2013); environmental concerns, and a preference to own electronic devices are also factors in this decision (Ibid). An international survey by Deloitte supports these findings - this survey suggested that young drivers (Generation Y) are more likely to give up their car when costs increase (Deloitte, 2014). The same survey also found that individuals from Generation Y preferred living in more walkable neighbourhoods and are more willing to use car-share programs than older generations (Ibid).

In the Greater Toronto Area (GTA), a survey conducted by Royal Bank and the Pembina Institute (Burda, 2012) found that 18-34 year olds had a stronger preference to live in mixed-use walkable neighbourhoods instead of more suburban locations despite the higher cost to rent and/or own than did 35-59 year olds (65\% versus 50\%). A second survey carried out by Pembina (Burda and Haines, 2012) found that drivers in the GTA were significantly interested in opportunities to reduce their commutes including improved rapid transit infrastructure, and telecommuting; this suggests that given appropriate opportunities GTA residents would drive less. Together these two surveys suggest that GTA residents are increasingly looking for alternative mobility and housing options that reduce their reliance on automobiles.

In Canada a voluntary annual car ownership survey carried out between 2000 and 2009 provides some insights into the trends of Canadians (Statistics Canada, 2014a; Statistics Canada, 2014b). It suggests that between 2000 and 2009 annual vehicle kilometers travelled (VKT) per vehicle declined steadily. When this data is combined with population data (Statistics Canada, 2014c) it suggests that VKT per person did not significantly change over this period of time. Similar results are obtained when isolating for Ontario. 


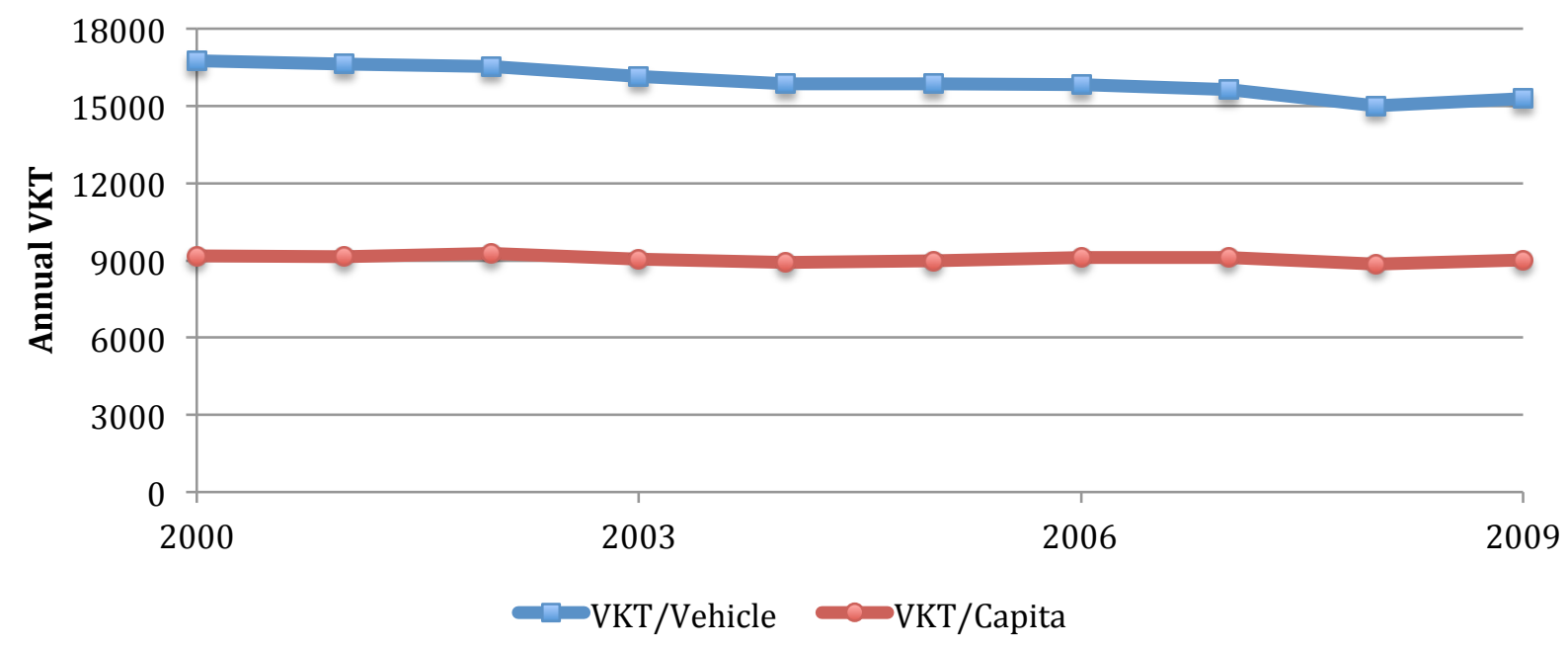

Figure 1: VKT/Vehicle and VKT/Capita in Canada

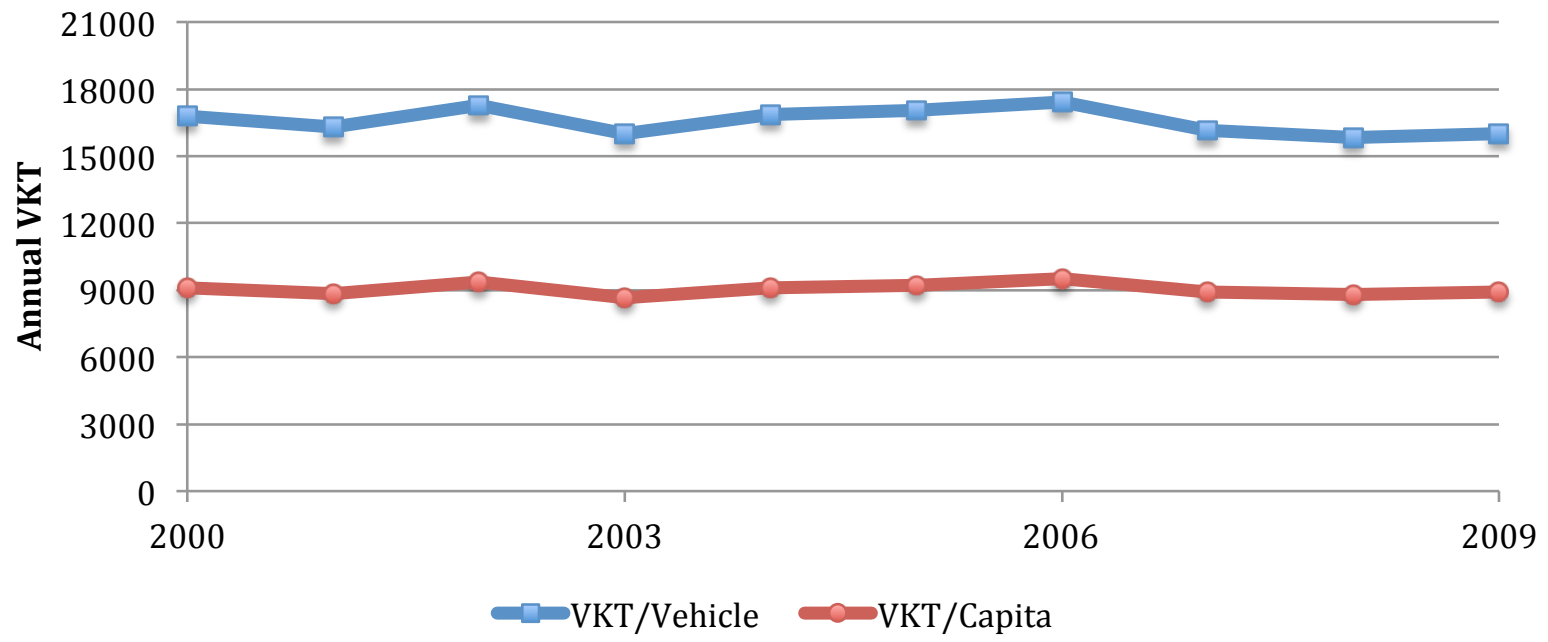

Figure 2: VKT/Vehicle and VKT/Capita in Ontario

\subsection{Policy directions}

Not only is there a trend towards less reliance on automobiles, but policy at both the Provincial level in Ontario, and Municipal level in Toronto promote this shift away from automobile dependency. The Growth Plan for the Greater Golden Horseshoe (Ministry of Infrastructure, 2013), Provincial Policy Statement (MMAH, 2014), and Toronto's Official Plan (City of Toronto, 2010) all directly 
call for a shift away from automobile travel and towards more sustainable forms of transportation including transit, and active transportation:

The Growth Plan states: "Population and employment growth will be accommodated by ... reducing dependence on the automobile through the development of mixed-use, transit-supportive, pedestrian-friendly urban environments" (Ministry of Infrastructure, 2013);

The Provincial Policy Statement (PPS) states that land use patterns should "minimize the length and number of vehicle trips, and support current and future us of transit and active transportation” (MMAH, 2014);

Toronto's Official Plan has a section entirely focused on transportation demand management, which recognizes that in a mature city such as Toronto there is a need to maximize the efficiency of the overall transportation system, and that this requires a reduction in reliance on the automobile (City of Toronto, 2010).

The PPS, Growth Plan and Official Plan are all required to be implemented through Toronto's zoning by-law. That is to say, Toronto's parking minimums, as part of the City's zoning by-law, should support the policies expressed in the PPS, Growth Plan and Official Plan.

\subsection{The justification for minimum parking requirements}

Historically minimum parking requirements were created in order to support automobile based mobility (ITDP, 2010). Most North American municipalities utilize parking minimums, and put these minimums into place during the $20^{\text {th }}$ century in order to ensure sufficient parking was provided for all automobile trips, and to minimize the impact that new developments would have on existing neighbourhoods and existing parking facilities, including on-street parking (ITDP, 2010). Toronto's official plan (City of Toronto, 2010) speaks directly to this goal of reducing impacts on existing neighbourhoods and their supply of parking: 


\section{"Developments in Mixed Use Areas, Regeneration Areas and Apartment Neigbbourboods that are}

adjacent or close to Neighbourboods will ... attenuate resulting traffic and parking impacts on adjacent neighbourbood streets so as not to significantly diminish the residential amenity of those

Neighbourboods."

Parking minimums were often developed around the assumption that the automobile was the preferred mode of travel, and that drivers should not be inconvenienced by having to seek parking it was better to oversupply parking than to undersupply it (ITDP, 2010). In this sense, parking minimums can be viewed as the result of planning for the automobile.

This history of parking requirements suggests that they are a relic of the past; they were developed in a time when cities were built and planned primarily around the automobile. With many jurisdictions exploring opportunities to reduce reliance on automobiles, including Toronto and Ontario, there is a strong justification for re-considering the need for parking minimums or, at a minimum, revising the process we use to set parking minimums in order to reflect these changing priorities.

\subsection{Establishing parking minimums}

Typically, parking minimums are set using three steps as outlined in the text box below (Shoup, 2011):

Step 1: A specific land use must be defined - Toronto for example has defined over 80 different land uses in its current zoning by-law. Examples of different land-uses in Toronto include dwelling units, offices, bowling alleys, and kennels (City of Toronto, 2013).

Step 2: For each land use, a basis for parking requirements is required. For example in Toronto parking in residential units is defined either by units or bedrooms; for most other land uses the City uses gross floor area as the basis. 
Step 3: An appropriate parking rate must be set - this rate states how much parking is required for the unit of measurement defined in step two. This is often the most challenging step: ideally the rate is determined through empirical surveys that help determine the demand for parking (IBI, 2005). However, many municipalities eschew conducting their own surveys and rely on established rates published by groups such as the Institute of Traffic Engineers, Urban Land Institute, or by comparing to other near by municipalities (Shoup, 2011).

Authors including Donald Shoup (2011) and Jeff Speck (2012) have pointed out the absurdity of some of the parking requirements that exist - for example swimming pool parking requirements based on gallons of pool water. Fortunately, residential parking requirements can use the number of units or number of bedrooms as a basis for parking that generally correlates well to auto-ownership and, accordingly, parking demand (Cansult, 2007).

\section{Critique of the traditional parking requirement methodology}

Donald Shoup (2011) significantly criticizes the practice of setting parking requirements, calling it a pseudo-science. In particular he suggests that empirical surveys used to identify parking demand typically lack sufficient data points to provide a strong basis for setting minimums and that surveys typically rely on sites with free parking. Another problem with the traditional methodology is that most references suggest parking ratios should correspond to the $85^{\text {th }}$ percentile for demand (IBI, 2005). By definition, this approach means that $85 \%$ of the time parking lots are not used to capacity - or alternatively that $85 \%$ of parking lots are too big (Shoup, 2011; IBI, 2005). Studies of actual parking utilization confirm this over-supply; many parking lots sit empty most of the time, even during peak periods. A 2002 survey of parking in downtown Seattle found that almost 40\% of parking spaces were empty (Shoup, 2011). 
When assessing parking rates another concern is that empirical surveys assess current demand for parking at existing sites. At most existing sites parking has traditionally been free and over-supplied, skewing the true demand for parking (Shoup, 2011). In developments where parking is priced, for example at condominiums with unbundled parking, relying on historical data including sites where parking is free, is likely to lead to an over-supply of parking. Historical parking rates are also blind to current transportation demand management (TDM) programs that have the goal of reducing automobile use in new developments. In fact, as will be discussed later in this review, the mere act of supplying parking encourages driving, and as a result, tying parking requirements to established demand levels might act in opposition to the goals of TDM programs (Willson, 2013).

\section{Shared parking requirements}

One way to make parking requirements more efficient is to allow for shared parking facilities (ULI, 2005). Shared parking requirement recognize that different land-uses require parking at different times of the day and that parking can be used more efficiently if land-uses could share parking facilities (Ibid). Figure 3 on the following page compares parking requirements for a hypothetical site in downtown Toronto using traditional parking requirements, and shared parking requirements. The approaches differ as follows:

- Under the traditional approach site parking requirements are defined by the sum of peak demands for each on site use.

- Under the shared parking approach total site parking requirements are calculated based on utilization factors for different times of the day. The site parking requirements are defined by the time period with the highest total demand. 


\begin{tabular}{|c|c|}
\hline \multicolumn{2}{|c|}{$\begin{array}{l}\text { Office } \\
2,000 \text { Square meters } \\
\text { Parking requirement: } \\
0.35 \text { spaces } / 100 \text { square meters } \\
\text { Spaces required: } 7\end{array}$} \\
\hline $\begin{array}{l}\text { Retail store } \\
1,000 \text { Sq. } \mathrm{m} . \\
\text { Parking req: } \\
1.0 \text { spaces per } \\
100 \text { sq. meters } \\
\text { Spaces req: } 10\end{array}$ & $\begin{array}{l}\text { Club } \\
1,000 \text { Sq. } \mathrm{m} . \\
\text { Parking req: } \\
3.0 \text { spaces per } \\
100 \text { sq. meters } \\
\text { Spaces req: } 30\end{array}$ \\
\hline
\end{tabular}

Traditional Approach

Sum of peak parking requirements defines requirements for the parking facility.

\section{Office \\ 2,000 Square meters \\ Parking requirement: \\ 0.35 spaces $/ 100$ square meters}

AM: $100 \%(7)$

PM: $60 \%$ (5)

Eve: $0 \% \quad(0)$

\begin{tabular}{|l|l|}
\hline Retail store & Club \\
1,000 Sq. $\mathrm{m}$. & 1,000 Sq. $\mathrm{m}$. \\
& \\
Parking req: & Parking req: \\
1.0 space per & 3.0 spaces per \\
100 sq. meters & 100 sq. meters \\
& \\
AM: $100 \%(2)$ & AM: $20 \%(8)$ \\
PM: $60 \% \quad(10)$ & PM: $100 \%(23)$ \\
Eve: $0 \% \quad(10)$ & Eve: $100 \%(30)$ \\
\hline
\end{tabular}

\section{Shared Approach}

Time period with the highest total demand defines site parking requirements.
AM: $7+2+8=17$
PM: $5+10+23=38$
Eve: $0+10+30=40$

\section{Site Parking Requirement: $\mathbf{4 0}$ spaces}

Figure 3: Comparison of traditional and shared parking requirement calculations

While shared parking requirements can hypothetically lead to significant reductions in parking supply - in the provided example parking requirements were reduced by $33 \%$ - in practice, reductions are often much more limited. In large part this is because many uses have some degree of overlap in terms of peak usage; for example, in Toronto the vast majority of uses had $100 \%$ usage during the PM time period (City of Toronto, 2013). Furthermore, at residential buildings, the focus of this report, opportunities for shared parking is limited - individual parking spots are typically 
owned by condominium residents and access to the parking area is often limited to residents of the building.

\section{Reducing the need for parking at residential buildings}

Many municipalities are exploring opportunities to reduce automobile dependency, and reduce the need for parking at new developments. In particular, many municipalities have developed reduced parking requirements based on access to transit, bicycle parking, and car-shares. Examples of how alternative mobility options can reduce parking requirements are summarized below:

Transit: Many cities reduce parking requirements for areas close to transit (IBI, 2005). In Toronto for example parking requirements are reduced for five different policy areas, based in large part on the level of transit service available (Cansult, 2007);

Car-Shares: A number of cities offer reduced parking requirements in exchange for the provision of car-share facilities. These reductions are offered since studies have found that the presence of carshare vehicle does reduce car ownership (Engel-Yan and Passmore, 2013; IBI, 2009). In Toronto the recommended exchange rate is approximately four parking spots per car-share spot (IBI, 2009);

Bicycle infrastructure: Some cities allow for reduced parking in exchange for the provision of on-site bicycle facilities including bike parking and/or a bike-share. While there is little research specifically tying the provision of bike infrastructure to car ownership, a membership survey of Washington D.C.'s bikeshare program Capital Bikeshare found that 5\% of members sold their car, and that $81 \%$ of these members attributed the bikeshare as part of the reason for the sale (LDA Consulting, 2013).

\section{A new method to set minimum parking requirements}

On the basis that the current methodology for determining parking minimums has traditionally led to an oversupply of parking Richard Willson (2013) re-considered the entire process and suggested a 
new methodology. One of the major changes suggested by Willson is that parking should be determined for smaller areas than cities as a whole; using big areas fails to capture the variation in parking demand that can occur across a city.

Willson suggests a 10-step process (outlined in the text box below) to determine parking requirements. The most significant departure from the current methodology is a consideration of future trends, as well as a consideration of the impact of other specific policies including parking pricing, promotion of alternative transportation modes, and changing land-use patterns. In this way Wilson's methodology attempts to capture the impact of demographic trends and policy decisions on top of strictly considering historical demand. While this methodology is more onerous than a traditional approach, it is an improvement and is more likely to better represent actual demand for parking both in the present, and throughout the life of a project.

Step 1 - Determine existing parking utilization: Existing parking utilization can be determined through an empirical survey or parking counts at similar sites.

Step 2 - Develop the future baseline rate: This step requires a target year for the parking requirement and is meant to capture the impact of regional trends on parking demand. The current year can be used if supply should match current demand; using a future year suggests that a modest undersupply now is offset by appropriate supply in the future.

Step 3 - Decide on the best basis for the rate: This step considers whether to base the parking rate on average demand, $85^{\text {th }}$ percentile demand, $33^{\text {rd }}$ percentile demand, or some other basis. Choosing the $85^{\text {th }}$ percentile suggests a policy choice is being made to oversupply parking and Willson recommends a lower basis.

Step 4 - Consider project and context adjustments: This step is meant to adjust for any sitespecific characteristics such as land-use, location, and transportation characteristics. For example, if the area is expected to intensify future parking demand could be lowered. 
Step 5 - Allow for parking pricing/unbundling/cash-out requirements: This step is intended to capture the impact that pricing would have on parking demand at the site. If parking is expected to be free no adjustment is required for this step.

Step 6 - Recognize and transit/shuttle/pedestrian/bicycle requirements: This step is meant to capture the impact of alternative transportation requirements made in the zoning by-law. This includes reductions in vehicle use associated with bike parking requirements, car-share parking spots and other transportation alternatives.

Step 7 - Examine the internal space use efficiency/circulation factor: This step allows for increases to parking requirements if the zoning code requires specific parking requirements for different user groups. Segmenting parking use reduces overall efficiency and this step is meant to capture these effects. This step can be skipped if parking is unsegmented and is expected to be used optimally.

Step 8 - Adjust on-site ratio to account for off-site accommodation of parking: This step allows parking rates to be adjusted if there is an expectation that some users will use off-site parking facilities including on-street parking, or commercial lots. If there is a goal to eliminate off-site parking this step can be skipped.

Step 9 - Evaluate possible internal shared parking requirements: This step considers if there are any opportunities to reduce site requirements on the basis of shared parking.

\section{Step 10 - Calculate expected parking utilization, evaluate results, and iterate toolkit: The} outcomes and impacts of the calculated parking requirements should be evaluated. The impact of these requirements on community goals and/or urban design might suggest changes to consideration made in previous steps and a re-calculation of requirements.

On the surface Willson's methodology does not seem particularly revolutionary; in fact it incorporates factors and trends that most would assume inform parking minimums. However, Willson's methodology is an improvement over the status quo because the status quo has consistently failed to consider factors and trends that affect parking demand (Shoup, 2011). The standard methodology used to establish parking requirements parking has viewed parking as an 
absolute requirement for mobility; Willson's methodology instead views parking as one of many options available for a municipality to improve mobility.

\subsection{Impacts of parking minimums}

The literature reviewed so far has established that:

1. Minimum parking requirements were traditionally developed and based on the assumption that the automobile was the preferred mode of travel. Requirements were set to make driving convenient and to reduce the impact of new development on the use of existing parking facilities including on-street parking;

2. Demographic trends, and policy aims of Ontario and Toronto, suggest a decreasing reliance on automobile travel in the future;

3. Current methodologies used to set minimum parking requirements are based on existing parking demand and unlikely to appropriately appraise actual demand at new sites. However, the methodology used could be updated to better capture the impacts of both trends and policies.

From there it can be suggested that given the current planning context, and the history and rationale of parking minimums, that minimum parking requirements lead to an over-supply of parking. The next section of the literature looks to understand the implications of over-supplying residential parking.

Numerous studies have pointed to a variety of negative impacts resulting from an over-supply of parking. These negative impacts include increased propensity to drive, decreased viability of development, and decreased affordability of both housing and consumer goods (ITDP, 2010; Litman, 2013; Shoup, 2011; Willson, 2013). A recent academic study (Garrick, et al, 2013) examined 
the impact that parking minimums had on six different cities. This study found that parking minimums inhibited development, fragmented cities, and supressed opportunities to walk, bike, or take transit. On this basis there is a strong imperative to re-consider parking requirements to ensure that negative outcomes and impacts are minimized. Specific impacts of parking requirements are individually considered in detail below.

\section{Impacts on mode choice}

One of the primary negative impacts associated with an over-supply of parking is an increased propensity drive - when parking is accessible and free, individuals are incentivized to drive (Shoup, 2011). Increasing the propensity to drive carries a number of negative impacts to society including increased congestion, increased greenhouse gas emissions, and increased road accidents. In Ontario, Metrolinx - the regional transportation authority in the Greater Toronto Area - has identified parking management as a key TDM tool, citing that "Parking management... when applied properly, has been shown to have a positive impact on encouraging sustainable travel options and in reducing the demand for the personal automobile" (Metrolinx, 2008).

A variety of studies have linked the cost of parking to propensity to drive. For example, a study of data from Toronto (Harider, N.D.), found that $85 \%$ of commuters with access to free parking at work drive, while only $30 \%$ of those without access to free parking drive. An econometric study of data from Vancouver found that increased parking prices would reduce single-occupant vehicle trips, though not to the same degree as road pricing (Washbrook, et al, 2006). Similarly, a study in Portland (Hess, 2001) found that with free parking 62\% of commuters would drive alone and $16 \%$ would use carpools; with a daily parking charge of $\$ 6,46 \%$ of commuters would drive alone and $4 \%$ would use carpools resulting in 21 fewer cars on the road per 100 commuters. 
While numerous studies have examined the impact of parking pricing on propensity to drive, there is significantly less literature that examines the impacts of residential parking supply. Fortunately, two recent academic studies in New York have attempted to quantify these impacts: One study found a clear relationship between guaranteed parking at home and a greater propensity to drive to work, even if the trip is well served by transit (Weinberger, 2012). A second study examined the impact of parking supply and parking convenience and found that household with access to convenient and certain home parking were more likely to make use of their vehicles (Guo, 2013).

\section{Impacts on affordability}

Providing parking carries a cost with it - underground parking, the norm for parking at condominiums in Toronto, costs above $\$ 40,000$ per stall (Altus, 2014; Speck, 2012). Developers need to recoup these and as a result these costs need to be passed on to buyers and/or renters (Shoup, 2011; Speck, 2012). This can be offset to a degree by unbundling parking from units and passing the cost of parking onto the user. However, in most cases developers are not able to recoup the full cost of building parking (Sightline, 2013). If the full-cost of building a parking spot (and making an appropriate profit) cannot be achieved through the sale or annual income tied to a parking unit then these costs need to be absorbed elsewhere. In residential buildings the only other opportunity to recoup losses is through the price of units or rents.

The Sightline Institute (2013) found that all residential units, even those without parking end up paying for parking - in rental buildings they found that up to $\$ 246$ of rents per unit is subsidizing the operation of parking. Todd Litman (2013) more directly examined how parking directly impacts the affordability of housing units. He found that one parking space per unit increases costs by about $12.5 \%$, and two parking spaces increase costs by about $25 \%$. 


\section{Impacts on development}

The inability to recoup the full cost of parking does not only impact affordability for condominium purchasers, it can also have significant impacts on development. If developers can pass the full burden of parking costs onto condominium purchasers then they can to a degree shield themselves from negative impacts. However, studies suggest that this is not the case and that parking requirements are negatively impacting developers. An academic study in Los Angeles found that parking minimums were leading to an oversupply of parking (Cutter and Franco, 2012). The study found that the marginal cost of providing additional parking was higher than the marginal value added to a property by providing this parking - in essence, developers were not able to recoup the full cost of parking, and were losing money as a result of parking requirements.

Given that parking requirements can affect a developer's bottom line it should come as no surprise that these requirements have the effect of limiting the type and amount of development that occurs. Parking adds to the cost of development and restricts developers from pursuing riskier/costlier projects such as affordable housing and brownfield redevelopment. An academic study in Los Angeles (Manville, 2010) found that by removing parking requirements more development occurred. In the absence of the parking requirements, developers provided less parking, and instead they provided both more housing and a wider variety of housing, in particular: housing in older buildings, in previously disinvested areas, and housing marketed toward non-drivers (Ibid).

The impacts of parking requirements are also being felt in Toronto. In Toronto, reductions to parking requirements have been a regular request from developers over the past two decades (Shoup, 2011). These requests, and the required consultation with municipalities can slow and complicate development proposals. Parking requirements also have a direct impact on project viability in Toronto. By requiring too much parking, minimums can significantly impact project 
economics. Brad Lamb, a condominium developer in Toronto, noted that he cannot sell the parking spots he was required to build by the City "I have 35 unsold parking spots... it's certainly not good business practice." (Harris, 2013).

\subsection{Public perception of parking requirements}

On the basis of the literature reviewed above it can be concluded that parking requirements are a relic from the past; a relic that restricts opportunities to reduce car dependence and that directly impacts affordability and development opportunities. It is certainly worth asking then, why do we still have parking minimums? One part of the equation is that parking requirements have been a part of zoning by-laws for so long and are entrenched there for the time being. A more significant part of the equation however is the public perception of parking and perceived need for parking.

Individuals are very protective of their access to parking, particularly cheap and convenient parking (Shoup, 2011). No North American municipality has fully eliminated parking minimums. Some municipalities such as San Francisco and Cincinnati have eliminated minimums close to transit, or downtown. In other cases, municipalities have tried to make similar changes and faced significant opposition to the proposal, for example Washington D.C. recently tried to eliminate parking minimums near transit stations. The proposal was cancelled based on community response. Washington's director of planning stated: "We listened, and people were really concerned about it ... The absolute no required parking was really wigging people out." (Weiner, 2013).

In Toronto there has not been a proposal to eliminate parking requirements, but there are regular arguments over parking requirements at condominiums. For the most part residents are concerned about impacts to their supply of on-street parking: "The neighbourhood here does not want people coming in and taking parking on the street. We don't have enough for the people that are here already." (Harris, 2013). This 
is a valid concern, in some areas of Toronto demand for curb parking is already outpacing supply, with waiting lists required to receive a permit.

One of the potential reasons that parking minimums are viewed as essential by many residents, and that changes to minimums are fought against so strongly is due to the fact that when compared to market parking rates, on-street parking permits are highly subsidized (Shoup, 2011). In Toronto for example a parking permit costs $\$ 14$ per month for someone with no access to on-site parking (City of Toronto, 2014). These prices are significantly less than market prices for parking, even outside of the downtown core:

Based on personal observations made December 2013, a municipal surface lot at Dundas and Euclid charges $\$ 1$ per half-hour, to a maximum of $\$ 7$ between $7 \mathrm{am}$ and $6 \mathrm{pm}$ and $\$ 4$ between $6 \mathrm{pm}$ and $7 \mathrm{am}$ - at these prices it would cost approximately $\$ 120$ per month to park a car every night - nine times more than the cost of a permit.

When we start to compare the cost of permit parking in Toronto ( $\$ 170$ per year) to the cost of parking at a new condominium the difference becomes even starker. An underground parking spot costing $\$ 50,000$ amortized over 25 years costs over $\$ 2,800$ per year (using an interest rate of $3 \%$ ) more than sixteen times the cost of a residential permit.

These significant differences in costs beg the question of whether Toronto's permits are appropriately priced, if there is a better way to manage parking supply holistically through appropriate pricing, and if this would reduce concerns around reduced parking requirements. There certainly would be opposition to increased parking prices however Shoup (2011) suggests this might be mitigated by funnelling parking revenue back into the neighbourhood where it is collected. 
2.7. Summary

The key findings of the literature review are summarized below:

- Parking minimums were developed to make driving easier and more convenient. Current trends and policies suggest that planning should focus on reducing automobile dependence;

- Alternative mobility options including transit proximity, car-shares, and bicycle infrastructure have all demonstrated the ability to reduce car ownership rates and the need for parking;

- Current parking minimums typically lead to an over-supply of parking. This over supply has a number of negative impacts including reduced development opportunities, reduced housing affordability, and encouraging continued automobile use.

- Overall, the outcomes associated with minimum parking requirements suggest that they act in opposition to the goal of reducing automobile dependence and negatively impact development feasibility. 


\section{Methodology}

The goals of this research project are to examine parking requirements in Toronto to determine their impacts; as noted in the introduction this work is seeking to answer the two following questions:

1. Are Toronto's minimum parking requirements actively and effectively implementing policy goals expressed by the Province and the City? In particular are Toronto's parking requirements reflective of goals to reduce dependence on automobile trips?

2. Are Toronto's parking requirements acting as a barrier to development?

The literature reviewed, in particular Donald Shoup's The High Cost of Free Parking (2011), suggests that minimum parking requirements are promoting the option to drive, and adversely impacting development. To determine if Toronto's minimum parking requirements are leading to an oversupply of parking, and having a negative impact on development, affordability and mode-choice, a two step research method was employed: First, Toronto's current parking requirements and the process used to create them were critically reviewed through policy analysis based on the academic research carried out; Second, residential condominium developers were interviewed. These field interviews were designed to establish a qualitative understanding of the impacts that the current parking minimums are having on the development community in Toronto.

\subsection{Policy Analysis}

In 2004 Toronto began the process of reviewing its zoning by-law. This process arose as a result of amalgamation and the need for better co-ordination of zoning requirements between formerly independent municipalities. Included in this process was a review of all parking standards in order to determine appropriate new rates - rates at residential units were informed by two studies, a phase 
one review of all parking standards carried out by IBI (2005) and a phase two study of parking at apartment and condominium buildings carried out by Cansult (2007).

The recommendations and outcomes of these reports are analyzed based on results of the academic literature review to help determine if the process used to set Toronto's minimums is likely to lead to any negative outcomes. The degree to which Toronto's current parking requirements contribute or detract from Toronto's ability to meet goals within the OP, PPS, and Growth Plan is also analyzed. In particular, impacts to development feasibility, and to mobility and mode-choice are examined.

\subsection{Interviews}

In order to gain a better understanding of how the new parking requirements are impacting the development community, seven residential developers that have built condominiums in Toronto were interviewed. The overall research method associated with these field interviews was proposed to and approved by Ryerson's Research Ethics Board.

Field interviews were selected as a tool since they allow for a qualitative understanding of a community (Neuman, 2011); in this case the goal was to gain a qualitative understanding of challenges facing the development community as a result of parking minimums. An interview guide (included in Appendix A) was created to facilitate productive dialogues during the field interviews. Key themes explored through the field interviews include discussions about how parking requirements impact project economics, whether the current parking minimums are set at an appropriate rate, and if minimum standards have any impact on developer behaviour at all (i.e. would they do things differently in the absence of minimums). These interviews also attempted to assess developer opinion of parking minimums, and any alternative policies they thought could be effective. 
To ensure that the developers approached for interviews were appropriate members of the development community, developers were selected on the basis that they had worked on projects in either Downtown Toronto, or other areas with a high-level of transit connectivity (i.e. along the subway, or along Avenues). Focussing on this community ensured that the interviews would result in a discussion about how parking requirements had impacted projects in areas where the City prioritizes transit and active transportation. Participants also had pre-existing relationships with Ryerson faculty. This pre-existing relationship offered a degree of validation around the developers' experience and credentials (Neuman, 2011).

The names of the interview participants, their employers, and associated projects have been kept confidential and nothing in this report has been directly attributed to comments made by specific individuals. Information was kept confidential to ensure that all interview subjects were protected from risk, and able to share confidential information (Neuman, 2011). All participants consented to the interviews and signed a consent form that outlined the professional risks and detailed the confidentiality provisions of the project that were designed to minimize these risks. 


\section{Parking Requirements in Toronto}

Prior to amalgamation every municipality in Metropolitan Toronto had its own zoning by-law(s) and associated parking requirements (IBI, 2005). In 2004, Toronto, post amalgamation, began the process of developing a new zoning by-law. This process led to the current zoning by-law, 569-2013. This zoning by-law was developed to unify zoning across the amalgamated city, and to simplify the development process. The process for creating the new zoning by-law also planned to introduce new regulations to help implement the City's Official Plan (IBI, 2005). In order to create the new comprehensive zoning by-law the City of Toronto undertook a number of studies to help determine what changes were required; to review and update parking requirements a two-phase process was used: First, all existing parking standards would be reviewed. Second, new citywide requirements would be proposed based on the review.

\subsection{Review of Phase 1:}

In 2005, IBI released the first consultant report evaluating Toronto's former parking standards. This report had three key deliverables:

1. A review of the existing parking standards across all the zoning by-laws in the former municipalities of Toronto;

2. A comparison of the parking standards in Toronto to those in other jurisdictions;

3. An evaluation of the need and approach for updating various parking standards in the new zoning by-law.

This report identified a high need to review the parking standards for multi-unit residential buildings (MURBs), including condominiums (IBI, 2005). The reasons identified were the wide range of standards applied across various areas of the city and a discrepancy in how different factors were 
considered - including tenure and transit proximity. Five guidelines for the development of new MURB parking requirements were outlined by this report and are summarized below (IBI, 2005):

- Parking maximums for residential buildings are self-enforcing are not required in the by-law;

- It should be possible to accommodate different parking requirements based on tenure (i.e. rental apartments vs. condominiums). Two approaches are possible - different standards or, higher parking at condominiums could be achieved using guidelines to determine appropriate parking (above the minimum rate for all MURBs) as a condition of condominium approval;

- Adopt a harmonized parking ratio for all MURBs - do not differentiate parking ratios for building size;

- Establish parking standards in MURBs based on bedroom count per residential unit;

- Reduce the parking requirements for MURBs in areas of the city with transit access - these include, the Downtown, the Centres, the Central Waterfront and the Avenues.

In addition this study suggested separate harmonized visitor parking requirements be adopted for each of the Downtown, the Centres, the Central Waterfront, the Avenues, and the other areas of the city (IBI, 2005).

\section{Critique of the phase one review}

Based on the body of literature studied there are three primary critiques of IBI's review of parking requirements in Toronto.

(1) The report is largely dismissive of the negative impacts that parking requirements have. While this report does recognize that there are negative impacts associated with parking minimums, and that some municipalities such as London (UK) had eliminated parking minimums, the 
recommendations viewed parking minimums as "necessary for the foreseeable future" (IBI, 2005). This dismissal runs counter to the literature reviewed which found that parking minimums have significant negative impacts (Garrick, et al, 2013) and that there are a number of policy alternatives available (Shoup, 2011).

(2) The report suggests that parking maximums are not necessary for residential building stating " $A s$ a general rule, residential dwelling are somewhat 'self-enforcing', where the cost of surplus parking is paid for directly by the developer or condominium owners" (IBI, 2005). If from an economic perspective if the price of parking is able to create self-enforced maximums then it also stands to reason that the economic demand for parking would create self-enforced minimums and that the report could have also suggested that an elimination of minimums was also possible.

The literature reviewed (Shoup, 2011) suggests that in the absence of parking developers will continue to provide parking that economically makes sense. The IBI group itself recognized that minimums have little impact when they reviewed commercial parking requirements (IBI Group, 2007): "The risk of inappropriate parking spill-over associated with low parking minimums is considered minimal, since if there is a perceived need for higher levels of off-street parking, commercial developments will typically provide the bigher supply to attract tenants and customers." From a residential developer's perspective, there are similar negative outcomes associated with under-supplying parking: a lack of parking harms developer ability to sell units (a significant financial cost) and developers can reasonably be expected to develop the supply of parking required to sell all of their residential units.

(3) The most significant critique of the phase one review is that it did not deviate from the status quo of parking policy, despite recognizing that there are negative impacts associated with the provisions of parking. Given this report created the scope for future parking requirement studies, adhering to the status quo limited opportunities for change. 


\subsection{Review of Phase 2}

In 2007 Cansult released the phase 2 parking study that examined parking at MURBs. The terms of reference for this project stated that revisions to the existing parking standard were to reflect:

- The parking needs of city residents as determined by surveys;

- Pro-transit policies that are included in the OP.

Key policies within the official plan identified by this study include (Cansult, 2007):

- Promotes growth that is less reliant on the private automobile;

- Calls for a transit-based growth strategy by directing development to areas with good transit while improving transit in major growth areas;

- Protects the physical character of Toronto's low-rise neighbourhoods;

In addition to recognizing the value of empirical surveys, and policies within the OP, the Cansult study also suggested that existing parking by-laws should be considered during the review as these by-laws were developed based on the experience and expertise of City staff and consultants.

To determine demand for parking Cansult carried out a series of surveys with condominium owners, and apartment dwellers across the city; responses to the survey were sorted based on location. Total responses by location and tenancy are outlined in the table below:

\begin{tabular}{|l|l|l|}
\cline { 2 - 3 } \multicolumn{1}{c|}{} & Rental Apartments & Condominiums \\
\hline Downtown core & 261 & 675 \\
\hline Downtown Toronto and central waterfront & 172 & 550 \\
\hline Designated centres & 237 & 643 \\
\hline Avenues on the subway & 101 & 282 \\
\hline Avenues well served by surface transit & 200 & 673 \\
\hline Rest of the City & 225 & 671 \\
\hline
\end{tabular}

Table 1: Residential Parking Survey Responses 
Based on survey results Cansult found that both location, and bedroom count had impacts on parking. Cansult found that building size did not have a significant impact on parking demand. Cansult also established that rental apartments and seniors' housing had lower parking demands than condominiums - in this report only demand and results for condominiums are considered and recommendations made by Cansult for other types of housing are not critically evaluated. Finally, results for parking demand at avenues along the subway, and at centres on the subway were similar and Cansult grouped these locations together in its recommended parking requirements.

\begin{tabular}{|l|r|r|r|r|}
\cline { 2 - 5 } \multicolumn{1}{c|}{} & Bachelor & 1BD & 2BD & 3+BD \\
\hline Downtown Core & 0.2 & 0.79 & 1.05 & 1.75 \\
\hline Downtown and Central Waterfront & 0.75 & 0.73 & 1.11 & 1.32 \\
\hline Centres \& Avenues near rapid transit stations & & 0.9 & 1.17 & 1.35 \\
\hline Avenues well served by surface transit & 0.5 & 0.92 & 1.14 & 1.1 \\
\hline Rest of the City & & 1.17 & 1.05 & 1.12 \\
\hline
\end{tabular}

1. Italicized and shaded cell values are based on fewer than 20 responses in the cell.

2. For blank cells less than 15 responses per building were received

Table 2: Condominium Auto Ownership (Vehicles/Unit). Adapted from Cansult, 2007.

On the basis of survey results Cansult established parking requirements for five different locations in Toronto. In order to reflect OP policies that recommend reduced reliance on automobiles Cansult suggested minimum parking requirements ranging from $65 \%$ of average auto-ownership downtown to $95 \%$ of average auto-ownership in the rest of the city. The final parking requirements reflected either maintenance of the status quo, or a slight reduction from existing parking requirements: 


\begin{tabular}{|c|c|c|c|c|c|c|c|c|c|c|}
\hline \multirow{3}{*}{ Location } & \multicolumn{8}{|c|}{ Resident Standard (to accommodate personal vehicles) } & \multirow{2}{*}{\multicolumn{2}{|c|}{ Visitor Parking }} \\
\hline & \multicolumn{2}{|c|}{ Bachelor } & \multicolumn{2}{|c|}{1 Bedroom } & \multicolumn{2}{|c|}{2 Bedrooms ${ }^{*}$} & \multicolumn{2}{|c|}{$3+$ Bedrooms } & & \\
\hline & $\overline{\text { Recommended }}$ & Existing & Recommended & Existing & Recommended & Existing & Recommended & Existing & Recommended & Existing \\
\hline Downtown Core & 0.30 & 0.30 & 0.50 & 0.50 & 0.70 & 0.75 & 0.90 & 1.20 & 0.10 & 0.06 \\
\hline \begin{tabular}{|l|} 
Downtown and \\
Central Waterfront
\end{tabular} & 0.30 & 0.30 & 0.50 & 0.50 & 0.80 & 0.95 & 1.00 & 1.20 & 0.10 & 0.06 \\
\hline $\begin{array}{l}\text { Centres and } \\
\text { Avenues on } \\
\text { Subway }^{1}\end{array}$ & 0.60 & $0.85-1.1$ & 0.70 & $0.85-1.1$ & 0.90 & 1.0-1.1 & 1.00 & 1.0-1.1 & 0.10 & $|0.1-0.25|$ \\
\hline $\begin{array}{l}\text { Other Avenues (well } \\
\text { served by Surface } \\
\text { Transit) }\end{array}$ & 0.70 & $\mathrm{n} / \mathrm{a}$ & 0.80 & $\mathrm{n} / \mathrm{a}$ & 0.90 & $\mathrm{n} / \mathrm{a}$ & 1.10 & $\mathrm{n} / \mathrm{a}$ & 0.15 & $\mathrm{n} / \mathrm{a}$ \\
\hline Rest of City ${ }^{2}$ & 0.80 & $0.39-1.25$ & 0.90 & $0.74-1.25$ & 1.00 & $0.95-1.25$ & 1.20 & $0.95-1.35$ & 0.20 & $0.2-0.25$ \\
\hline
\end{tabular}

Notes:

1. York -NYC condo standards (within $500 \mathrm{~m}$ of rapid transit)

2. Range of standards for various locations

Table 3: Cansult proposed residential parking requirements (Cansult, 2007)

In making these recommendations, Cansult noted that for main street style development on avenues, parking can be difficult and expensive to develop and that alternative provisions including shared parking, off-site parking, and reductions for TDM measures should be considered.

\section{Critique of the phase two study}

Cansult's methodology used to determine parking demand - surveys of residents at condominiums has some advantages. In particular the methodology is effective for determining auto-ownership based on unit type/number of bedrooms. However this approach does have a number of limitations that reduce the reliability of Cansult's results and may lead to a misrepresentation of parking demand. First, using household automobile ownership rates creates an artificial sense of significance in the results due to the relatively high number of responses - parking requirements are based on parking usage at the building level, not the individual level, and an equal number of sites would have been surveyed by measuring utilization at two to three condominium buildings. More specific critiques are outlined below: 
- There is no clear indication of the number of sites surveyed in each policy area, only number of responses. Even in the downtown core where there was 675 responses this could have come from a small number of buildings;

- There is no indication of the geographic spread of surveyed sites within each areageography, even within the sub-areas, may play a significant role in determining parking demand;

- Survey results do not represent parking utilization - not everyone uses their parking 100\% of the time (Willson, 2013);

- Does not consider the amount of parking supplied at surveyed sites. Parking supply has an impact on auto-ownership - sites with an over-supply of parking encourage car ownership (Shoup, 2011);

- Does not consider the impact of pricing parking at sites surveyed- sites with free parking encourage car ownership (Shoup, 2011);

- Building age was not discussed beyond stating that all buildings surveyed were built since 1975. Since 1975 urban planning practices, mobility trends, and planning policies have all changed and as a result newer buildings are likely to have different parking demands than older buildings.

These critiques of Cansult's methodology are largely in line with Shoup's (2011) critique of the methodology used by the Institute of Traffic Engineers - insufficient data to draw appropriate conclusions, and inappropriate data points that do not account for appropriate parking policy.

One positive from Cansult's work is that they based parking requirements on average autooccupancy; many sources suggest utilizing $85^{\text {th }}$ percentile results (IBI, 2005) and such an approach would have lead to higher parking requirements. Cansult further reduced these parking requirements 
to between $65 \%$ and $95 \%$ of average automobile demand; while this reduction ensures that there is the option to provide parking below the average demand at existing sites there are still problems with this approach:

- The methodology used will lead to an over-supply at some sites - in a standard distribution setting parking requirements based on average occupancy ensures that $50 \%$ of sites will be over-supplied. For this reason Willson (2013) has suggested that $33^{\text {rd }}$ percentile might be a better initial basis, which will lead to fewer sites that are over-supplied.

- The justification for and application of reductions to automobile ownership is unclear. It is safe to assume that these reductions are meant to apply and account for policies within the OP that recommend reduced automobile dependence. However a more significant discussion of how the different reduction factors were arrived at for each area of the city is warranted.

A final critique of Cansult's methodology is that it failed to study auto ownership trends to determine how parking demand has changed over time, and will continue to change. As the literature review suggested, auto ownership is decreasing within the general population, and the decrease is even more pronounced with younger generations (Baxandall, Davis and Dutzik, 2012). By basing parking requirements on existing auto-ownership rates this exercise fails to create the space for reduced parking requirements that reflect changing mobility trends and policy goals.

\subsection{Assessment of the Current Parking Requirements}

Under the current zoning by-law (569-2013), Toronto has set minimum parking standards for five different locations across the city: Policy Area 1: Downtown, Policy Area 2: Centres on subways (i.e. Yonge and Eglinton), Policy Area 3: Avenues on subways, Policy Area 4, Other Avenues; Rest of 
the City. The parking minimums and maximums (where applicable) for each policy area are summarized below. For the most part Toronto has applied the recommendations from Cansult's report.

\begin{tabular}{|l|l|l|l|l|l|l|l|l|l|l|}
\cline { 2 - 10 } \multicolumn{1}{c|}{} & \multicolumn{4}{c|}{ Minimums (per unit) } & \multicolumn{5}{c|}{ Maximums (per unit) } \\
\cline { 2 - 11 } \multicolumn{1}{c|}{} & Bach. & 1BD & 2BD & 3+BD & Vis. & Bach. & 1BD & 2BD & 3+BD & Vis. \\
\hline PA1 & 0.3 & 0.5 & 0.8 & 1 & 0.1 & 0.4 & 0.7 & 1.2 & 1.5 & N/A \\
PA2 & 0.6 & 0.7 & 0.9 & 1 & 0.1 & 0.9 & 1 & 1.3 & 1.5 & N/A \\
PA3 & 0.6 & 0.7 & 0.9 & 1 & 0.1 & 0.9 & 1 & 1.3 & 1.5 & N/A \\
PA4 & 0.7 & 0.8 & 0.9 & 1 & 0.15 & 1 & 1.2 & 1.3 & 1.6 & N/A \\
Rest of City & 0.8 & 0.9 & 1 & 1.2 & 0.2 & N/A & N/A & N/A & N/A & N/A \\
\hline
\end{tabular}

Table 4: City of Toronto Parking Minimums and Maximums (City of Toronto, 2013)

The only significant change from Cansult's work is that there is only one downtown zone, rather than two. This zone applies the higher parking requirements to the entire downtown area. Cansult found that parking requirements in the downtown core - the area bounded by Simcoe street to the west, Victoria Street to the East, Queen Street to the North, and the Gardiner to the South - had lower parking requirement than the larger overall downtown area. As a result, the parking requirements set by Toronto require more parking than warranted in the downtown core.

Furthermore, despite Cansult's recommendations these requirements do not allow for off-site parking, or shared parking along for developments along avenues. There has been some work however to allow for reductions based on TDM measures - in particular the city allows for a reduction based on the provision of car-share facilities.

IBI's (2005) review of parking standards in Toronto found that Toronto's existing requirements were in line with those at other municipalities in Canada. Given that the Phase Two study did not recommend significant deviations from the former requirements it is expected that the current requirements remain similar to those in other municipalities. 


\section{Critique of 'Toronto's Current Parking Requirements}

Overall, the critiques applied to Cansult's work apply to the city's current parking requirements and these requirements are likely to lead to an oversupply at a significant number of new development sites due to a number of factors:

- Parking demand and the resulting requirements are based on existing sites which may not reflect current conditions including the price of parking and supply of parking (Shoup, 2011);

- Parking demand and the resulting requirements do not reflect changing mobility trends, nor policies which encourage reduced automobile reliance;

The most significant problem with Toronto's parking requirements is that they are based on current auto-ownership rates, and, by design, limit opportunities for reduced auto-ownership by mandating that access to parking is not significantly reduced from current levels. As the academic research found, access to parking is significant motivator when making the decision to drive (Weinberger, 2012). Given that Toronto's current minimum parking requirements, established in 2013, did not lead to a significant reduction in parking requirements, these requirements can be seen as indirectly promoting automobile based travel and acting in opposition to the Official Plan and provincial policy which both call for reduced automobile dependence. Given that there are a number of negative outcomes associated with over-supply of parking (Garrick, et al, 2013; Shoup, 2011), outcomes that act in opposition to goals of the OP and provincial policy documents, there is a strong argument to be made that these parking requirements should be reformed. 


\section{Developer Interviews}

Interviews were carried out with seven condominium developers to further assess the on-the-ground impacts of Toronto's current parking requirements and to better assess how parking requirements could be reformed. Results of these interviews are considered qualitatively in order to assess the impacts of the parking requirements. These key outcomes are based on general consensus from the developers interviewed; divergent viewpoints are noted and discussed where relevant.

\subsection{Key themes}

Theme \#1: Location and target market have the most significant impact on parking

Location: Developers suggested that condominiums built downtown typically have low demand for parking. Likewise those with strong access to transit also have low demand for parking. The developers all recognized that these areas had lower parking requirements than the rest of the city, however many gave examples of projects in which demand for parking still did not meet these reduced requirements for parking - at one downtown project where numbers were provided, current sales projections suggested that over $30 \%$ of parking would not be sold. It was suggested that this trend exists because many individuals who chose to purchase condominiums in these neighbourhoods are doing so since they see the opportunity to live without a car.

Target Market: All developers interviewed suggested that parking demand was highly dependent on unit type. Small units, such as bachelors, frequently had no demand for parking. On the other hand larger units, particularly units targeted at families, would be difficult to sell without parking. There was also a suggestion from developers that units sold to investors had lower demand for parking than those that were marketed directly to the expected occupants. It was suggested that the 
lower demand for parking at smaller units might be an issue of cost - individuals buying smaller units are less likely to want to spend $\$ 50,000$ on parking when their unit only cost $\$ 300,000$.

\section{Theme \#2: Parking typically generates losses, not profits}

All developers interviewed suggested that parking was either a loss leader, or at best a breakeven proposition for most sites. The developers interviewed suggested that underground parking units cost between $\$ 40,000$ and $\$ 75,000$ and could typically be sold for between $\$ 20,000$ and $\$ 50,000$. These costs raise the question of how these losses are being covered and suggest that, even though parking has been unbundled from condominiums, residents with access to parking are not paying the full cost of this parking.

Theme \#3: Parking supply has had an impact on the current price of residential units Selling parking at a loss means that these losses must be absorbed elsewhere - in the case of condominiums the only opportunity to recoup these losses is increased prices on residential units. While most developers suggested that parking has had impact on the price of residential units they

all suggested that removing parking requirements would not have an immediate impact on the price or affordability of residential units. This is because, as one developer stated, the markets for condominiums and parking are separate and their prices are independently determined and evaluated when assessing a development opportunity. Another developer argued that some level of parking is typically required for development, and that there may be justification for all residents paying some of these costs since they have benefited from the development.

This outcome suggests that there is a need to better understand the economics of parking and underground development, how parking prices are set, and how this impacts the price of all residential units. 


\section{Theme \#4: Parking requirements reduce development feasibility}

Two developers commented that the costs associated with parking make it difficult to redevelop some properties. For sites with other factors that already present economic barriers (e.g. mid-rise sites, brownfields, and narrow lots) the additional losses generated by parking might make redevelopment unfeasible. Eliminating required parking, and the some of the losses associated with parking, might allow more sites to be re-developed.

No developer suggested that parking requirements had stopped them from proceeding with a proposed project - developers understand the requirements and costs of parking and this is part of any site assessment. Developers instead are not considering sites where the economics of parking supply make re-development unfeasible.

On the basis of this outcome, it is possible that if parking requirements were reduced, and developers provided less parking, additional costs might accrue elsewhere on balance sheets - for example the cost of land could increase since developers would have more ability to pay.

\section{Theme \#5: Eliminating parking minimums would not significantly impact the amount of} parking supplied

All developers suggested that eliminating the minimums would not have a significant impact on parking supply. Developers noted that they look to build the parking required to sell the units in their condominiums - where this requires building more than the minimums, more parking is built; where this requires less parking than the minimums developers seek a reduction to the requirements. Despite this, two developers suggested there is risk in eliminating minimums as the minimums do provide a level of assurance that all developers will act responsibly and provide some parking. 


\subsection{Other observations from interviews:}

A number of other relevant findings occurred from the interviews:

Parking does not only directly cost money; it adds time to the development process by requiring underground construction. Reducing parking requirements would therefore not only reduce project costs, but also reduce development timelines, further increasing the feasibility of re-development.

In Toronto, parking requirements are political and dictated by councillors: The majority of developers independently (i.e. this was not a direct question) noted that willingness to reduce parking varies significantly between different Toronto councillors - some are very amenable to reductions in requirements, while others much more stringently apply the requirements.

In general, the City is willing to grant minor variances for parking when reductions of $10-15 \%$ are requested. In addition there are examples of reducing parking requirements, on the basis of parking sales, after a condominium has gone to market; this suggests that there is some willingness for the City to consider reduced parking requirements based on market conditions.

\subsection{Summary of Interviews}

The interviews carried out suggest that parking is having an impact on the development community in Toronto. In particular parking does not typically generate profits for developers. As a result of this parking requirements have had an impact on the cost of residential units and have reduced development feasibility. These findings are in line with the literature review, and further support the need to re-consider Toronto's current parking requirements. 


\section{Conclusions and Recommendations}

Toronto's current minimum parking requirements are based on providing at least enough parking to meet existing auto-ownership rates; they do not reflect changing mobility trends or policies that encourage a shift away from automobile based travel. On this basis Toronto's current parking requirements are leading to an over-supply of parking, and in turn leading to negative outcomes. Three key negative outcomes were identified through developer interviews and policy analysis:

(1) Parking requirements have impacted housing prices: even at sites with unbundled parking the development of parking facilities creates a cost rather than profit for most developments, a cost which is absorbed into the price of all residential units. Determining the degree to which parking impacts housing prices warrants a more thorough economic study.

(2) Parking requirements have increased the cost of development and as a result they have reduced development feasibility. Since parking creates a loss for most developments it also restricts the ability to redevelop some sites, particularly those with other challenges (e.g. brownfields, midrise buildings, and narrow lots).

(3) Parking requirements have limited the opportunity to reduce automobile dependency. The provision of parking subsidizes and encourages individuals to maintain ownership of their cars and to continue to drive. Since parking requirements are set based on current automobile ownership rates rather than target rates there is limited opportunity to create behavior change.

These outcomes are in opposition to directives within the OP, PPS and Growth Plan; directives that the zoning by-law is meant to implement. These outcomes are also in opposition to trends and preferences of younger generations who have a preference for living in walkable neighbourhoods, and a reduced preference for auto-ownership compared to older generations. 


\subsection{Recommendations}

On the basis that Toronto's current parking minimums are not creating positive outcomes three recommendations have been developed, one of these recommendations is an overall policy recommendation directed at municipal planners, one is a recommendation directed towards all urban planners, and the last is a recommendation directed at developers.

\section{Recommendation 1: Municipal planners should reform Toronto's parking requirements}

Historically, there was a fear that without sufficient parking requirements, developers would not build enough parking, saddling municipalities with parking supply issues (Shoup, 2011). Both the literature reviewed, and the interviews carried out with developers suggest that this is no long the case; the market has evolved to stage where developers are aware of the parking required to lease, and/or sell property. Based on the analysis carried out it can be fairly stated that Toronto's parking requirements as currently structured are not effective; they act as a barrier to development, and they act in opposition to the goal of reducing automobile dependence. On this basis six options to reform parking requirements are considered.

Assessing the policy window for these changes to occur is more challenging. Immediately reforming Toronto's parking requirements certainly makes the most sense on the basis that despite the fact that the parking requirements are relatively new they are already leading to negative outcomes. A more realistic timeline might be to overhaul parking requirements in line with an Official Plan review or zoning by-law overhaul. A specific opportunity might be to critically reconsider parking requirements at the neighbourhood level under the development permit system being considered by the City of Toronto through the ResetTO initiative.

Option 1 (preferred) - Eliminate minimum parking requirements: Municipalities such as London (UK) have eliminated parking minimums and replaced them with parking maximums 
(Greater London Authority, 2011). This change recognizes that minimum parking requirements detract from, rather than support, a shift away from automobile based travel, and would allow parking policy to reflect the goal of reducing automobile ownership. Parking maximums could be set based on current auto-ownership rates, this would allow developers to continue to provide parking in line with demand at most sites, but also allow developers to strategically reduce parking at sites where demand was lower. Where parking minimums suggest we must provide at least enough parking, switching to maximums instead suggests that we provide no more parking than what is required.

Option 2 - Reduced minimum parking requirements: As an alternative to eliminating minimum parking requirements, the requirement could be reduced significantly based on Willson's methodology (2013). For this option a comprehensive review of requirements should be carried out in order to determine the expected impact of changing mobility trends and current policy goals - in specific this review should be used to set parking requirements at target auto-ownership rates (i.e. where we want average auto-ownership to be in 5-10 years) rather than current ownership rates as is currently done. This would allow developers to build sites with less parking than currently required through the zoning by-law, but still leave room for developers to build sites based on current average auto-ownership required if they desired.

Option 3 - Parking cap \& trade: The City of Toronto could implement a parking cap and trade system that would allow nearby developments to transfer parking requirements (Robinson, 2014). In particular this could be used to provide more parking at luxury condominiums or family condominiums where developers interviewed suggested there is a higher demand for parking, while reducing parking provided for condominiums with predominantly smaller units.

Option 4 - Shared parking at condominiums: Another opportunity to reform parking usage at condominiums would be to allow shared parking. Instead of selling parking units, condominiums 
could sell parking permits (similar to on-street permits sold by Toronto) that guarantees overnight parking, but allows for outside use during other times of the day. During the daytime these lots could act as commercial lots. There are three benefits to this options: (1) increased parking utilization throughout the day; (2) additional parking revenue from non-resident; (3) more efficient use of parking infrastructure is possible without specific parking stalls being owned (Willson, 2013).

Option 5 - Use existing infrastructure more effectively: Underground parking lots are not the only place where condominium residents can park, parking is also available on-street and in local parking facilities. Better use of these facilities could reduce the need to develop expensive underground parking. In particular, overnight use of existing commercial and municipal lots is typically low and could provide off-site parking for many condominiums. This option is in line with municipal and provincial goals of using existing infrastructure more efficiently (City of Toronto, 2010; MMAH, 2014).

Option 6-Manage parking at a neighbourhood level: Parking supply requirements could be set at a neighbourhood scale rather than site-specific scale. Target parking and/or auto-ownership rates could be set for the overall neighbourhood and all parking facilities within a neighbourhood could count towards meeting the requirements. This would allow for new developments to be considered within the overall neighbourhood context of parking supply, rather than as isolated silos. This approach would still require appropriate parking requirements, in line with policy goals, to be set at the neighbourhood level.

\section{Recommendation 2: Urban planners require better education about parking}

Shoup (2011) has argued that planners are not educated about parking and fail to recognize the impacts that parking supply has. Reviewing the methodology used to set Toronto's parking requirements suggests that this is the case; negative impacts are largely dismissed and parking is 
viewed as a basic requirement. Further evidence that planners fail to recognize the impact of parking comes in The Ontario Professional Planners Institute recent Call to Action encouraging planners to better support and implement active transportation (OPPI, 2014). While the literature suggests that parking supply presents a barrier to this call to action by fragmenting cities, and encouraging automobile based travel (Garrick, et al, 2013), the OPPI's call to action does not once mention the impact of automobile parking.

If planners as a profession wish to encourage active transportation and transit friendly neighbourhoods they need to recognize that minimum parking requirements are presenting a significant barrier to these goals. It is likely that, in line with Shoup's critique (2011), planners require better education around the impacts of parking if significant change on this front is expected. My education as Master's student in Urban Planning did not include a critical consideration of how parking requirements impact either mobility options or smart growth goals; there was only a small discussion about the costs of parking. It would be entirely fair to say that without this research project I would have been unable to critically comment on parking policy, and the same is likely true of other professional planners - they have not been trained to adequately assess parking.

This need for education also extends to politicians. As developers noted, in Toronto parking requirements are political and councillors make the final decision regarding requirements. Ensuring that politicians are better educated about the impacts of parking would help them make more informed decisions. Finally municipal engineers also likely require better education, something Shoup (2011) has noted. As with my education as planner, my undergraduate education in civil engineering did not include a critical discussion of parking requirements. Municipal engineers play a significant role in assessing the parking requirements at new development sites and a better understanding of parking would help them make more informed assessments and analyses. 


\section{Recommendation 3: Developers should track and publish parking sales}

Municipal planners and engineers are not solely responsible for current parking requirements being set where they are. While developers interviewed consistently suggested that parking requirements were too high, there is a lack of official data supporting these claims. In order to support policy change, developers should be more forthcoming about parking sales and parking demand at new developments. More proactive developers could also provide the tools to track parking usage at their developments. This data would help better inform future parking studies.

\subsection{Conclusions}

This research has highlighted that while parking might traditionally be viewed as a mundane topic and beyond critical consideration for most planners, parking requirements are significantly impacting planning outcomes even in mature, successful urban areas such as Toronto. As planners and municipalities increasingly adopt New Urbanism and Smart Growth policies, and as mobility preferences continue to trend away from automobile based travel, pressure will be placed on planners to critically consider all components of our transportation systems, including parking.

In many ways, parking requirements echo thinking about urban freeways. Both were a result of planning for the automobile. Thinking around freeways has evolved, and is now recognizing that mobility can often be more effectively provided via other means. A similar shift is required in our thinking about parking. Parking can no longer be viewed as only an amenity required to support our cities and our ability to drive; instead it must be viewed as a significant economic investment that carries with it outcomes that shape our cities and regions. We need to recognize that parking carries significant costs, that it heavily subsidizes the choice to drive, and that there are other solutions available to planners and engineers as we seek to ensure that all residents have access to adequate mobility. 


\section{Appendix A - Interview Guide}

\section{Introduction}

Thank you for taking the time to meet today, I really appreciate it. Before we get into questions I wanted to remind about you the subject of my research, review how information from this interview will be used, and answer any concerns that you may have.

As I outlined to you when setting up this interview my MRP will assess how Toronto's parking policies - in specific minimum parking requirements in the zoning by-law - influence Toronto's stated policy goals of increasing intensification in key areas and encouraging modes of travel other than automobile. While the focus of this work will be on policy analysis and case study research, I am interviewing at least six developers, including you, to help ensure that my critiques and recommendations are in line with those made by professionals working on the ground in Toronto. This MRP will be published through creative commons and be available online, it will also be available to future students through Ryerson's digital collection of student research papers.

Throughout the interview I'll be taking notes that I will later destroy after transcribing digitally. To ensure that your responses are protected these files will be stored on a password protected computer, and backed-up online in a password protected account. Following the completion of this project these digital files will be destroyed.

Nothing said in this interview will be directly attributed to you, or any projects you participated in. Likewise, your participation in this study will be kept anonymous - neither your firm nor your name will be used to identify you. You will also have the opportunity to review all information/quotes that result from this interview prior to publication of my MRP. If at any point during the interview you would like something removed from the record, please let me know. 


\section{Questions}

\section{Part 1 - Parking minimums}

1. What is your experience in the development industry here in Toronto? How many projects has your firm built in downtown Toronto or other growth areas such as along designated avenues?

2. I'd like to explore how Toronto's parking policies have affected projects that you have been involved with. How have Toronto's Parking minimums affected your ability to advance new developments (commercial or residential)?

3. Have you ever proposed a reduction to parking minimums? How was this proposal met by the city?

4. If Toronto eliminated parking minimums how would this impact future developments by your firm? Follow-up - What level of parking do you anticipate that you would provide?

\section{Part 4-Alternatives to parking}

5. What alternatives have you considered offering to your buyers for mobility, for example, transit passes, car shares, bike parking?

6. In your experience, do these alternatives help reduce the demand for parking? Which alternatives have you found to be most effective and why? Have some alternatives been generally ineffective?

\section{Part 5 - Improving Toronto's Parking Policies}

7. What changes would you make to parking policies in higher density neighbourhoods in Toronto? [provide cues about parking minimums, curb parking, residential permits as required] 
8. Based on your experience, if you could develop a parking regime for Toronto that would meet the needs of your buyers what would it look like? This could include changes to policy or consideration of alternatives to parking. 


\section{References}

Altus Group (2014). Construction Cost Guide 2014.

Baxandall, P., Davis, B., and Dutzik, T. (2012). Transportation and the New Generation Why Young People Are Driving Less and What It Means for Transportation Policy. Retrieved from:

http://www.uspirg.org/sites/pirg/files/reports/Transportation $\% 20 \% 26 \% 20$ the $\% 20 \mathrm{New} \% 20 \mathrm{Gene}$ ration $\% 20 v U S \_0 . p d f$

Ben-Joseph, E. (2012). ReThinking a Lot: The Design and Culture of Parking. Cambridge, Mass: MIT Press.

Burda, C. (2012). RBC-Pembina Home Location Study: Understanding where Greater Toronto Area residents prefer to live. Retrieved from: http://pubs.pembina.org/reports/rbc-pembina-home-locationstudy.pdf

Burda, C. and Haines, G. (2012). Drivers' Choice: Options to manage gridlock and fund rapid transit in the GTA: Public opinion survey and policy options. Retrieved from: http://pubs.pembina.org/reports/driverschoice-gta-report.pdf

Cansult (2007). Parking Standards Review - Phase Two Apartment Building / Multi-Block Development Component, New Zoning By-Law Project. City of Toronto. Retrieved from:

http://www1.toronto.ca/city_of_toronto/city_planning/zoning_environment/files/pdf/cansult_f inal_apart_stds.pdf

City of Toronto. (2010). Official Plan: Office Consolidation 2010.

City of Toronto (2013). By-law 569-2013.

City of Toronto (2014). "Permit Parking." Accessed March 15, 2014 at:

http://www1.toronto.ca/wps/portal/contentonly?vgnextoid=bec6a84c9f6e1410VgnVCM10000071 $\underline{\text { d60f89RCRD\&vgnextchannel=cd4c4074781e1410VgnVCM10000071d60f89RCRD. }}$. 
Cutter, B. and Franco, S. (2012). "Do parking requirements significantly increase the area dedicated to parking? A test of the effect of parking requirements values in Los Angeles County." Transportation Research Part A, 46, p. 905-925.

Deloitte (2014). 2014 Global Automotive Consumer Study: Exploring consumers' mobility choices and transportation decisions. Retrieved from: http://www.deloitte.com/assets/Dcom-

UnitedStates/Local\%20Assets/Documents/us_auto_GlobalAutomotiveConsumerStudy_012314.pd $\underline{f}$

Engel-Yan, J. and Passmore, D. (2013). "Carsharing and Car Ownership at the Building Scale." Journal of the American Planning Association, Vol. 79, No. 1, p. 82-91.

McCahill, C. et al. (2013). "Parking in Urban Centers: Policies, Supplies and Implications in Six Cities”. Submitted to Transportation Research Board, Novermber 15, 2013.

Greater London Authority (2011). The London Plan 2011. Retrieved from: http://www.london.gov.uk/priorities/planning/publications/the-london-plan

Guo, Z. (2013). "Does residential parking supply affect household car ownership? The case of New York City." Journal of Transport Geography, 26, p. 18-28

Haider, M. (N.D.) Impact of Free Parking, Transit Accessibility, and Socio-Demographic Attribute on Mode Choice in Toronto. Accessed March 15, 2013 at:

http://milute.mcgill.ca/Research/Senior/Final_Draft_Parking_July04.pdf

Harris, A. (2013). "Parking issues: New condominium building triggers car alarm in the Beach." Toronto Star, February 24, 2013.

Hess, D. (2001). The Effects of Free Parking on Commuter Mode Choice: Evidence from Travel Diary Data. The Ralph \& Goldy Lewis Center for Regional Policy Studies, UCLA, School of Public Policy and Social Research.

IBI Group (2005). Parking and Loading Zoning Standards Review. Phase One. New Zoning By-Law Project. City of Toronto. Retrieved from:

http://www1.toronto.ca/city_of_toronto/city_planning/zoning_environment/files/pdf/ibi_phas e1_report.pdf 
IBI Group (2007). Review of the City of Toronto Zoning By-Law Parking Standards for Office, Retail and Restaurant Uses. City of Toronto. Retrieved from:

http://www1.toronto.ca/city_of_toronto/city_planning/zoning_environment/files/pdf/ibi_parki ng_2007.pdf

IBI Group. (2009). Parking standards review: Examination of potential options and impacts of car share programs on parking standards, 2009. City of Toronto. Retrieved from:

http://www1.toronto.ca/city_of_toronto/city_planning/zoning_environment/files/pdf/car_shar e_2009-04-02.pdf

Institute for Transportation and Development Policy. (2010). U.S. Parking Policies: an overview of Management Strategies. Retrieved from:

https://go.itdp.org/download/attachments/51251185/ITDP_US_Parking_Report.pdf?version=1\& $\underline{\text { modificationDate }=1391715260003 \& a \mathrm{pi}=\mathrm{v} 2}$

LDA Consulting (2013). 2013 Capital Bikeshare Member Survey Report. Retrieved from:

http://capitalbikeshare.com/assets/pdf/CABI-2013SurveyReport.pdf

Litman, T. (2013). Parking Requirement Impacts on Housing Affordability. Victoria Transportation Policy Institute. Retrieved from: http://www.vtpi.org/park-hou.pdf

Manville, M. (2010). Parking Requirements as a barrier to bousing development: regulation and reform in Los Angeles. Lewis Center for Regional Policy Studies, Institute of Transportation Studies, UCLA.

Metrolinx (2008). Development Of A Regional Transportation Plan For The Greater Toronto And Hamilton Area; Green Paper \#4: Transportation Demand Management. Retrieved from: http://www.metrolinx.com/en/docs/pdf/board_agenda/20080207/Appendix_A__TDM_Draft_Green_Paper_4.pdf

Millar-Ball, A. (2002). "Putting their parking caps on.” Planning, April 16-21.

Ministry of Infrastructure (2013). The Growth Plan for the Greater Golden Horseshoe.

Ministry of Municipal Affairs and Housing (2014). Provincial Policy Statement. 
Neuman, Lawrence W (2011). Social research methods: qualitative and quantitative approaches. 7 th ed. USA: Pearson.

Ommeren, J. V., and Wentink, D. (2012). “The (hidden) cost of employer parking policies.” International Economic Review, Vol. 53, No. 3.

Ontario Professional Planning Institute (2014). Healthy Active Transportation: Moving Forward on Active Transportation in Ontario's Communities. Retrieved from: http://ontarioplanners.ca/PDF/HealthyCommunities/2014/Moving-Forward-on-Active-Transportation-in-Ontario

Robinson, P. (2014). Personal Conversation at Ryerson School of Urban Planning, March 2014.

Shoup, D. (2011). The High Cost of Free Parking. American Planning Association (Planners Press).

Schoette, B. and Sivak, M. (2013). "The reasons for the recent decline in young driver licensing in the U.S." University of Michigan.

Sightline Institute (2013). Who Pays for Parking: How the oversupply of parking undermines housing affordability. Retrieved from: http://www.sightline.org/wpcontent/uploads/downloads/2013/12/Who-Pays-for-Parking-Sightline-Dec-2013.pdf

Sivak, Michael (2014). "Has motorization in the U.S. peaked? Part 4, households without a light-duty vehicle." University of Michigan.

Sivak, Michael (2013). "Has motorization in the U.S. peaked? Part 2: use of light-duty vehicles." University of Michigan.

Speck, Jeff (2012). Walkable City. New York: Farrar, Straus and Giroux.

Statistics Canada (2014a). Table 405-0055 - Canadian vehicle survey, number of vehicles on the registration lists, by type of vehicle, province and territory, annual (units), CANSIM (database). Accessed: 2014-03-27.

Statistics Canada (2014b). Table 405-0058 - Canadian vehicle survey, vehicle-kilometres, by type of vehicle, province and territory, annual (vehicle-kilometres), CANSIM (database). Accessed: 201403-27. 
Statistics Canada (2014c). Table 051-0001 - Estimates of population, by age group and sex for July 1, Canada, provinces and territories, annual (persons unless otherwise noted), CANSIM (database). Accessed: 2014-03-27.

Urban Land Institute (2005). Shared Parking. Washington, D.C.: ULI.

Washbrook, K., W. Haider, and M. Jaccard. 2006. "Estimating commuter mode choice: A discrete choice analysis of the impacts of road pricing and parking charges". Transportation, 33(6): p. 621-639.

Weiner, A. (2013). “Tregoning: Parking Minimum Elimination Was "Really Wigging People Out.” Washington City Paper, July 12, 2013.

Weinberger, R. (2012). "Death by a thousand curb-cuts: Evidence on the effect of minimum parking requirements on the choice to drive." Transport Policy, 20, p. 93-102.

Willson, Richard (2013). Parking Reform Made Easy. Washington, D.C.: Island Press. 